\title{
Preface
}

\author{
No matter how contrasts between generations have \\ been created, one fundamental fact of life remains \\ true in the United States: Generations matter. To \\ understand other people, and even to fully understand \\ ourselves, we must consider generational identity \\ at least as carefully as we consider any other social \\ characteristic.
}

ELWOOD CARLSON

In the fall semester of 2009, I taught a studio class in collaboration with the local chapter of Habitat for Humanity. Habitat's architect joined me one day a week in class and Habitat staff periodically reviewed progress. Families already living in Habitat homes also offered their input. Students used building information modelling (BIM) software to ensure that their houses met Habitat's budget and to empirically prove the cost-effectiveness of each home's featured sustainability. At the semester's final review, a jury selected one student's design to advance toward construction, with Habitat's architect offering the winning designer and the first runner-up paid internships to finish the construction documents over winter break. The students' solidarity was so high that they continued working together, submitting the semester's work to a National Council of Architectural Registration Boards (NCARB) competition, and the project won the coveted $\$ 25,000$ grand prize. That accomplishment was pivotal in my being appointed director of the New Jersey School of Architecture in 2010.

Great story, right? The part I have withheld thus far is how much I absolutely dreaded teaching that studio. My dread centered on the belief that no student would want to design an affordable house in what was known as the 
"Options" year, when our curriculum typically offered a choice of formally exotic or theory-driven studios. Our faculty expected students would crave the artistic freedom of Options after three years of an extremely rigid core curriculum. Things had been this way since I began teaching, and along with my faculty colleagues, I saw no reason for change. Habitat's property committee chair, who is a neighbor and friend, had been pestering me for years to take on the task of the collaborative class. Each year I found an excuse, knowing Options presented the only slot in our curriculum to fit a studio like Habitat's. But when a research studio's funding fell through weeks before the semester began and I needed a design assignment, I finally gave in; "Let's get this out of the way," I thought. Setting expectations exceedingly low, I forecast to Habitat that we would be the last choice in the studio lottery, as few students would voluntarily choose a project assignment with the profound constraints of a small affordable house amidst such a rich array of other choices. And given the role GPA played in prioritizing choices, I surmised that this would also mean that the lowest-performing students would be "stuck" with the studio and it would feel remedial. They would toil away while others forayed into the esoteric. I braced for the worst.

To my shock and surprise, demand for the studio was exceptionally high; many students listed it as their first choice. The studio filled mostly with honors students, so many that the associate dean respectfully asked if I could share some with the other studios. When I later queried students about what attracted them, their responses were largely consistent: they spoke of wanting to do something real that would matter to them. I learned, to my surprise, that many considered the typical Options studios to be faculty indulgences that offered students few practical lessons in preparation for their careers. One student even referred to them as "fantasy studios." And in the economic recession in which we then found ourselves, many students considered formal exploration for its own sake to be irresponsible. Students also jumped at the opportunity to use BIM and its range of functionality, expecting that proficiency would give them a leg up when vying for jobs after graduation. They knew those faculty members interested in formal exploration typically frowned upon BIM, preferring more formally generative software. The most prominent attraction students cited was the civic purpose of the studio, which would allow students to play an active role in providing for those in need. To a local newspaper, the winning student described the studio's mission as "noble." "You're not trying to give people a shelter, but a home," he said. ${ }^{1}$ 
I recognized only later that this was my personal introduction to the Millennial generation. The overarching practicality and civic focus of those students were characteristics I later learned to be significant to their generation. That the studio functioned successfully in a highly collaborative manner, not only among students but also within the larger Habitat community, revealed another Millennial tendency: team-centeredness. While this kind of studio was not entirely novel-community-focused studios had been around since the sixties-its use of digital strategies was a key to its success. Differing from the traditional design-build studio, it achieved a high level of virtual resolution, both aesthetic and practical, in a relatively short period of time, with designers obtaining community buy-in through both highly realistic renderings and data-supported rationales. The studio also exhibited other, more quirky Millennial characteristics; students quickly taught themselves how to use the cost-estimating functions of BIM and developed work-arounds for the finicky relationship between BIM and the environmental modelling software, which at that time was poorly integrated. To my amazement, they did so by largely ignoring the computer industry reps brought in to lecture them, instead opting to scan the web for online tutorials and chat rooms to teach themselves. To make his project the most environmentally sustainable, the winning designer not only found a newly developed heat exchanger but also convinced the company to discount it for Habitat and found a state program to fund it. He pursued this winning strategy entirely online and on his own initiative.

The following year, as one of my first acts as director, I convened a faculty colloquium to discuss our current pedagogy. It was in that undertaking that I first became aware of Millennials. The experience of the prior year snapped into focus after our university librarian, who had been assiduously studying Millennials for many years, spoke to our group. I was surprised (and somewhat embarrassed) to find that the generation had then been in higher education for about a decade. How did I miss this, especially with a leading scholar on the subject on campus? I discovered that many different kinds of writers had been studying this generation, some from the time Millennials were small children; somehow, they not only knew they were coming, but forecast their features. Collectively, these writers had identified distinct Millennial characteristics, and their scholarship had reached a point that healthy disagreement and discussion had emerged between different camps. I also learned that Millennials are digital natives, and as a pure function of when I was born, I will always remain a digital immigrant. To my distress, 
I found that their digital inheritance was instrumental in Millennials' ability to profoundly change industries, social structures, politics, you name it. I nervously came to realize that any organizational structure was vulnerable to this large wave of youth empowered with digital know-how and that this reorganizational phenomenon had a name: a disruption.

Why was I not aware of these disruptors in our midst? I asked others about Millennials near and far and got raised eyebrows; "You mean Gen Y or those Nexters?" some responded. Few knew anything about them. Among my faculty colleagues, most shared the misconception that students' aspirations had not changed significantly in the years since we were in school-the same fallacy that caused me to dread the Habitat studio. I soon began to realize that changes occurring around me, those that I simply chalked up in the vague category of technological progress, were driven by Millennials' active and total embrace of technology as digital natives. This also made me worry. After all, the recording industry had lost half its value in less than a decade, newspapers were closing all around us, and MIT, Harvard, and Stanford had begun offering their courses online, and for free. Closer to home, enrollment in architecture schools, including my own, progressively began to slip. While most attributed this to the recession, I wondered if other factors were at work and if my complacent academic community was next to be disrupted. When in early 2013 the American Institute of Architecture's journal Architect put a Millennial on the cover and called for "drastic changes to pedagogy, licensure and firm management," 2 | realized that my community had stirred and something needed to be done. That awakening drives this book.

Millennials in Architecture: Generations, Disruption, and the Legacy of a Profession calls for architectural practice and education to embrace and take seriously this catalytic generation. Doing so will utilize the Millennial generation to its greatest advantage as we move forward through a turbulent period, one in which the architectural community will be asked to play a disproportionately large role in shaping our physical world. In the coming decades the earth's population will increase by over a third, with two-thirds of its people moving to cities. This reconfiguration will be largely driven by demographic change, with Millennials playing the lead role, and the success of this transformation will depend increasingly on Millennial leadership. The degree to which climate change and political unrest will further induce migration may dramatically increase urbanization and its associated issues. Rising to the challenge of solving them will test the organizational abilities of the practices doing the work and the ability of academia to teach those 
who will undertake it. Acknowledging Millennials in architecture as disruptors, grooming them for leadership, and accepting the standards of education they expect will have great bearing on the future quality of life of the whole population.

Focusing directly on these coming challenges, this book emerges at a critical moment as Millennial architects near becoming a majority in the workforce and are and will for some time remain a majority in schools. This vantage allows for the evaluation of early writing on Millennials and the comparison of those findings and predictions with contemporary data and personal testimony specific to architecture. To use a meteorological metaphor, architecture also finds itself at a kind of midpoint, in the eye of a slow-moving storm of Millennial disruption. In the calm of its eye, architectural practices enjoy renewal after the deepest economic recession in recent memory caused severe layoffs. As the economy revives and Millennials fill vacant seats, taking advantage of this pause to understand and accommodate the generation will best prepare architecture practices for the trials ahead when the tempest resumes. This will involve mobilizing the many Millennial assets, but also reckoning with the challenges some have identified in dealing with the generation. The second half of the storm, I believe, will bring a dramatic disruption that will not leave architectural schools unscathed. And how the architectural academy weathers this disruption will in turn have direct bearing on the success of the architectural profession.

The stakes are indeed high. For years architects have been complaining about erosion to their agency. But if the needs of architecture's Millennials go unanswered, the changes to come may be marshaled forward by sectors other than architecture, leaving the profession yet further marginalized and perhaps permanently damaged after this disruptive storm passes. Examples of Millennial-driven disruptions now abound. Who could have predicted that a search engine company, Google, would usurp the lead from the once allpowerful automobile industry in the development of autonomous vehicles? ${ }^{3}$ And the fact that BIM software is creeping toward automation should make every architect shudder. The coming years will decide which side of the algorithm architects will be on: writing the software or being dominated by those who do.

The organizational structure of this book places the reader at the eye of the storm, in the present. This allows the reader to pivot three times: looking first to the past, then analyzing the present critically through a 
generational understanding, and, finally, speculating about the future. Part One begins with a critical assessment of Millennials' relationship to architecture in the beginning of the twenty-first century and continues with a close examination of the generation and its relationship to previous ones going back to the early twentieth century. I apply the methodology of different generational writers to this examination, including that of the historians William Strauss and Neil Howe, two of the most prolific and controversial contemporary writers on generations. Part One concludes by applying a generational overlay to the history of American architecture going back to modernism. Part Two pivots to reconsider the present, beginning with a review of recent texts that reveals generational layers in architecture's profession and academy. Recognizing these layers is essential in moving forward, allowing the highest possible mobilization of Millennial assets by turning perceived challenges into opportunities for change. This examination looks closely at Millennial behaviors and characteristics and how they positively or negatively affect architectural practice and education, including each attribute's digital underpinnings. Millennials in Architecture concludes in Part Three by scouting the profound disruption that digital technology will bring, a reconnaissance that informs on how to embark on the drastic changes to pedagogy, licensure, and firm management that the American Institute of Architects expects.

This book targets multiple and overlapping audiences. While its primary focus is on the community of architects in practice-designers, managers, and employees-and those in the academy-administrators, teachers, and students-it should also resonate among the broader design community, the boundaries of which seem to be fluid. While an important purpose of this book is to make all aware of the disruption ahead, its larger intent is to position architecture to take advantage of generational characteristics to effectively prepare for what will be a major building age. In its lowest form, this work begrudgingly accepts its role as a self-help book that explains to managers and employees in the profession why each group seems befuddled by the other's expectations, to the academy why students question whether a career in architecture is worth the effort, and to professors whether Millennials' efforts can withstand architecture's historically difficult demands. Yet the explanation of each of these conflicts underscores the loftier aspiration of this book: to show how an awareness of the special relationship between Millennials and the practice of architecture can reorganize and expand its domain in both pedagogy and practical methodology. The general char- 
acteristics that we ascribe to Millennials, such as civic-mindedness and a team focus, have always been central to the architect's identity. That architecture embraced digital practices in both the profession and the academy well before other disciplines suggests another alliance. If understood as proto-Millennial in its makeup, the architecture community can take advantage of its unique gifts to empower the rising generation for future leadership positions in architecture and beyond. For those that share this argument-whatever generation they identify with; whether they are part of the architectural community or outside it-this book serves as a manifesto.

My most coveted audience is also this book's primary subject. I truly hope that you, the disruptors, whether employed, still in school, or somewhere on a margin-and whether you identify as Millennial or not-read this book. While some of you may agree with the generalized findings, surely as many will respond to some characteristic with skepticism, saying, "That's not me." To those skeptics, I ask you to first consider the arguments in their entirety and not to invalidate the whole undertaking because of individual or local points of disagreement. This book is meant to inspire precisely this consideration, as it is my sincerest goal that you bring the debate it incites to your studios, offices, agencies, social media, blogs, and beyond. Any study that describes and contrasts the generalized characteristics of an entire generation must spark contention not only from the generation described but also from its elders and its juniors. I have faith that your generation of disruptors will use this book as a call to action.

In igniting this discussion, I see tremendous profit in positing the characterizations I have isolated and in describing the rich interplay between generations past, current, and anticipated for an audience to consider and debate. My own Habitat epiphany regarding Millennials came after a combined thirty years of practice and teaching, and I bring to this new understanding the zeal of a convert. I have spent the time since immersed in generational scholarship while at the same time carefully observing the many students I serve and how my faculty colleagues interact with them. Parallel to this, I have also taken the time to query architects, both Millennial and older, through online polling and in focus groups. Serving as a form of architectural correspondent from the eye of this storm, I render here as accurate an assessment as possible, using my professional awareness tempered by an academic's skepticism to prompt a long overdue discussion, one that I hope can lead to lasting change. In its most fundamental ambition, this book calls those in architecture to see themselves in a manner that some 
of us have seldom, if ever, done: as an active participant in a generation. This simple step will cause us to give renewed attention to the remarkable time we live in, to who we are, to the students we teach, the individuals we employ, and the people we learn from and work for, and most importantly to the constituents we all serve, as together we contemplate our place in time and history. 


\section{Millennials in Architecture}


THIS PAGE INTENTIONALLY LEFT BLANK 